\title{
STATUS HAK CIPTA SEBAGAI HARTA SEPENCARIAN MENURUT PERSPEKTIF PERUNDANGAN SYARIAH
}

\section{(The Status of Copyright as Jointly Acquired Property According to the Syariah Perspective)}

\author{
Muhammad Farahin Mazlan* \\ farahinpaen099@gmail.com
}

Mohd Zamro Muda

zamro@ukm.edu.my

Jabatan Syariah, Fakulti Pengajian Islam, Universiti Kebangsaan Malaysia.

Pengarang koresponden (Corresponding author): *

Rujukan artikel ini (To cite this article): Muhammad Farahin Mazlan \& Mohd Zamro Muda. (2022) Status hak cipta sebagai harta sepencarian menurut perspektif perundangan syariah. Kanun: Jurnal Undang-undang Malaysia, 34(1), 23-44. http://doi.org. 10.37052/kanun.34(1)no2

\begin{tabular}{|c|c|c|c|c|c|c|c|}
\hline $\begin{array}{l}\text { Peroleh: } \\
\text { Received: }\end{array}$ & $1 / 7 / 2021$ & $\begin{array}{l}\text { Semakan: } \\
\text { Revised }\end{array}$ & $9 / 9 / 2021$ & $\begin{array}{l}\text { Terima: } \\
\text { Accepted: }\end{array}$ & $19 / 9 / 2021$ & $\begin{array}{l}\text { Terbit dalam talian: } \\
\text { Published online }\end{array}$ & $2 / 1 / 2022$ \\
\hline
\end{tabular}

\footnotetext{
Abstrak

Peruntukan undang-undang keluarga Islam menyebut apa-apa aset yang diperoleh dalam tempoh perkahwinan boleh dituntut sebagai harta sepencarian. Namun begitu, status hak cipta sebagai harta sepencarian masih menjadi perdebatan. Oleh itu, objektif kajian bertujuan mengenal pasti konsep hak cipta sebagai harta sepencarian menurut perspektif perundangan syariah dan menganalisis status hak cipta sebagai harta sepencarian menurut pendapat ahli dan pengamal perundangan syariah. Reka bentuk kajian adalah secara kualitatif, iaitu analisis dokumen dan temu bual separa berstruktur. Data diperoleh melalui statut hak cipta dan harta sepencarian di Malaysia, fiqh empat mazhab sunni serta temu bual bersama-sama pengamal perundangan syariah, ahli hak cipta dan ahli agamawan. Dapatan kajian mendapati Islam mengiktiraf status hak cipta dalam harta sepencarian. Hak cipta juga termasuk dalam kategori harta tidak ketara yang boleh dituntut

(C) Dewan Bahasa dan Pustaka. 2022. This work is licensed under the term of the Creative Commons Attribution (CC BY) (http://creative commons.org/licenses/by/4.0/) 
sebagai harta sepencarian jika dimiliki dalam tempoh perkahwinan atau dikembangkan dalam tempoh perkahwinan dengan melihat pada faktor sumbangan pihak suami dan isteri dalam perolehan harta tersebut. Hasil temu bual mendapati para informan menyokong teori hak cipta sebagai harta sepencarian. Implikasi kajian ini memberikan sumbangan dalam kajian ilmu syariah dan boleh dirujuk oleh mahkamah syariah dan sivil untuk menangani masalah hak cipta sebagai harta sepencarian. Kajian juga mencadangkan penggubalan undang-undang berkaitan dengan hak cipta dan harta sepencarian berkenaan harta yang boleh dituntut sebagai harta sepencarian.

Kata kunci: Perundangan, syariah, perkahwinan, harta sepencarian, hak cipta, harta tak ketara

\section{Abstract}

The provisions of Islamic family law state that any asset acquired during the period of marriage can be claimed as jointly acquired property. However, the status of copyright as jointly acquired property is still debatable. The objective of this study is to identify the concept of copyright as jointly acquired property according to the perspective of Sharia law and to analyze copyright as jointly acquired property according to the opinions of Sharia practitioners and experts. The research framework is qualitative, which applies document analysis design and semi-structured interviews. The data were obtained through the statutes of copyright and jointly acquired property in Malaysia, the fiqh of the four Sunni schools of thought as well as interviews of Sharia legal practitioners, copyright law experts, and religious scholars. The findings of this study showed that Islam recognizes copyright in jointly acquired property. It also can be recognized as intangible property that can be claimed as jointly acquired property if it is owned or developed during the period of marriage by looking at the contribution factor of the husband and wife in acquiring the property. The results of the interviews also showed that the informants support the theory of copyright as jointly acquired property. The research implication is to contribute to the study of Sharia and as a reference for the Sharia and civil courts in dealing with the issue of copyright as jointly acquired property. This study also proposes that legislators enact laws that are related to copyright and jointly acquired property, and also property that can be claimed as jointly acquired property.

Keywords: Legislation, Sharia, marriage, jointly acquired property, copyright, intangible property 


\section{PENDAHULUAN}

Walaupun tidak terdapat peruntukan khusus berkenaan dengan status hak cipta sebagai harta, namun harta tersebut dikategorikan sebagai harta tidak ketara atau dikenali sebagai incorporeal property dan intangible property menurut sivil (D. Moore, 1998). Dari aspek Islam, ulama kontemporari mengkategorikannya sebagai hak yang bersifat maknawi atau haq almanawiyyah (al-Khafif, 1966). Secara asasnya, terdapat tiga hak pada hak cipta dan salah satunya ialah hak ekonomi. Menurut Akta Hak Cipta 1987, hak ekonomi membolehkan pemilik hak cipta memperoleh ganjaran daripada hasil karyanya. Selain itu, pemilik hak cipta juga boleh melakukan pindah milik hak ekonomi tersebut melalui kaedah penyerahan hak, penberian wasiat dan kuat kuasa undang-undang. Berdasarkan hal tersebut, timbul isu berkenaan statusnya sebagai harta sepencarian. Hal ini kerana, Akta Undang-Undang Keluarga Islam (Wilayah-Wilayah Persekutuan) 1984 memperuntukkan dalam Seksyen 58(1):

\footnotetext{
Mahkamah adalah mempunyai kuasa, apabila membuat suatu perintah perceraian, memerintahkan supaya apa-apa aset yang diperolehi oleh pihak-pihak itu dalam masa perkahwinan dengan usaha bersama mereka dibahagikan antara mereka atau mana-mana aset itu dijual dan hasil jualan itu dibahagi antara pihak-pihak itu.
}

Peruntukan tersebut menggunakan lafaz yang umum, iaitu "apa-apa aset" yang diperoleh dalam tempoh perkahwinan boleh dituntut sebagai harta sepencarian. Hal inilah yang menimbulkan persoalan sama ada bolehkah hak cipta termasuk dalam kategori harta sepencarian?

Hal tersebut juga memberikan kesan kepada Akta Hak Cipta kerana peruntukan Akta Hak Cipta 1987 tidak menyatakan pindah miliknya sebagai kategori tersebut. Selain itu, pada masa kini, tuntutan harta sepencarian bukan sahaja melibatkan tanah atau rumah, bahkan melibatkan sebarang jenis harta sama ada harta alih atau harta tidak alih (Miszairi \& Akmal Hidayah, 2010; Mohd Nurhusairi, 2014). Selain harta alih dan harta tak alih, menurut Ibrahim \& Abd Ghadas (2017), harta tak ketara seperti faedah masa hadapan dan modal insan juga pernah dituntut sebagai harta sepencarian. Namun demikian, di negara Eropah dan di Amerika, mahkamah menolak kes yang berkaitan dengan tuntutan harta tidak ketara sebagai harta sepencarian. Menurut mereka, harta tidak ketara ini tidak termasuk dalam kategori harta. Keputusan tersebut turut memberikan kesan kepada pendapat sarjana yang mengkategorikan harta intelek 
sebagai incorporeal property atau intangible property (Salmond, 1913; D. Moore, 1998). Isu berkenaan status hak cipta sebagai harta sepencarian juga pernah dibangkitkan oleh Ibrahim (2010) dalam kertas seminarnya yang bertajuk "Harta Sepencarian: Konsep dan Amalan". Oleh itu, berdasarkan permasalahan tersebut, pengkaji menganalisis status hak cipta sebagai harta sepencarian menurut perspektif perundangan dan syariah di Malaysia. Selain itu, pendapat ahli hak cipta dan pengamal perundangan syariah juga turut dibincangkan bagi menyokong dapatan kajian.

\section{TEORI HAK CIPTA SEBAGAI HARTA SEPENCARIAN MENURUT PERUNDANGAN SYARIAH}

\section{Pandangan yang Menolak Hak Cipta sebagai Harta Sepencarian}

Secara asasnya, tidak terdapat sebarang kenyataan yang jelas berhubung dengan pendapat yang menolak hak cipta dikategorikan sebagai harta sepencarian. Namun demikian, hal ini dapat dirumuskan berdasarkan perbincangan teori harta yang akan dibincangkan oleh pengkaji lepas, iaitu berkenaan dengan konsep harta. Berdasarkan perbincangan tersebut, terdapat beberapa pendapat yang menolak hak cipta sebagai harta sepencarian antaranya termasuklah pendapat mazhab Hanafi yang berdasarkan kepada teori harta mazhab ini. Menurut Ibnu Abidin (2003), harta ialah sesuatu yang mempunyai sifat nyata (objek) atau fizikal. Selain itu menurut mazhab tersebut, hak cipta termasuk dalam kategori hak dan manfaat. Teori ini turut disokong oleh pendapat Imam al-Qarafi (1998) yang menyatakan bahawa ijtihad ialah hasil buah fikiran yang merupakan hak penulis atau penciptanya dan tidak boleh dikategorikannya sebagai harta. Hasil buah fikiran juga tidak boleh dijadikan objek warisan, wasiat dan transaksi.

Selain itu, Ibn Hazm (2015) juga turut mengemukakan pandangan yang sama bahawa hak cipta tidak boleh dijadikan objek pemilikan. Hal ini kerana menurut beliau, transaksi buku dibenarkan kerana benda yang sedang diniagakan ialah buku dan dakwat. Buku bukanlah hasil gambaran idea tersebut. Berdasarkan perbincangan tersebut, jelas menunjukkan bahawa terdapat pandangan yang menolak hak cipta sebagai harta sepencarian. Walau bagaimanapun, seperti yang dinyatakan oleh pengkaji, tidak terdapat satu perbincangan yang jelas mengatakan bahawa hak cipta tidak boleh dikategorikan sebagai harta sepencarian. Sarjana Islam hanya membincangkan hak cipta sebagai kategori harta sahaja. Namun 
demikian, sarjana Islam yang menolak hak cipta sebagai harta ini jelas meletakkannya tidak boleh dijadikan objek transaksi, warisan dan wasiat. Jika hak cipta tidak boleh dijadikan objek transaksi, maka hak cipta juga tidak boleh dikategorikan sebagai harta sepencarian.

\section{Pandangan yang Menerima Hak Cipta sebagai Harta Sepencarian}

Terdapat beberapa teori yang menunjukkan bahawa hak cipta boleh dikategorikan sebagai harta sepencarian. Teori yang pertama, hak cipta termasuk dalam definisi dan kategori harta seperti yang telah dibincangkan oleh fuqaha. Hujah yang pertama, hak cipta merupakan sesuatu yang bernilai dan termasuk dalam definisi harta yang diutarakan oleh Imam alSuyuti (1983). Selain itu, hak cipta juga dikategorikan sebagai harta kerana hak cipta memiliki manfaat menurut al-Zarkashi (2000), al-Maqdisi (2000) dan al-Bahuti (2000). Hak cipta juga termasuk dalam definisi pemilikan, iaitu sebagai sesuatu harta yang boleh dimiliki menurut Abu Umar seperti yang dipetik oleh Abd al-Barr (1998). Dari segi jenisnya pula, hak cipta termasuk sebagai kategori harta mutaqawwam atau harta yang boleh dimanfaatkan menurut syarak. Hal ini menunjukkan bahawa, hak cipta diiktiraf sebagai harta sepencarian kerana termasuk dalam definisi dan kategori harta yang dibincangkan oleh fuqaha.

Selain hujah tersebut, hak cipta juga boleh dikategorikan sebagai harta sepencarian dengan melihat konsep harta sepencarian. Suwaid (1996) menyimpulkan bahawa istilah harta sepencarian adalah seperti yang berikut:

Istilah yang ditentukan terhadap harta alih atau harta tak alih yang diperoleh hasil daripada usaha atau carian bersama, sama ada secara langsung atau tidak langsung dalam bentuk sumbangan modal, tenaga atau moral yang telah disumbangkan oleh suami dan isteri dalam tempoh perkahwinan mereka sama ada harta itu didaftarkan atas nama satu pihak atau nama bersama.

Berdasarkan definisi tersebut, Suwaid (1996) meletakkan "harta alih dan harta tak alih" bagi menjelaskan maksud harta yang boleh dituntut sebagai harta sepencarian. Dari segi pengertiannya, harta alih (manqul) bermaksud harta yang boleh dipindahkan dari satu tempat ke satu tempat seperti kenderaan dan perabot. Harta tak alih (aqar) pula bermaksud harta yang tidak boleh dipindahkan seperti tanah dan bangunan (Majallat al-Ahkam al-Adliyyah; al-Zuhayli, 1985). Jika menggunakan teori 
harta alih dan harta tak alih, hak cipta tidak termasuk dalam kategori harta yang boleh dituntut sebagai sepencarian. Hal ini kerana, hak cipta diklasifikasikan sebagai harta tak ketara. Selain itu, al-Durayni (1981) telah mengemukakan perbezaan antara manfaat daripada hak cipta dan manfaat daripada harta tak alih (al-aqarat) serta harta alih (al-manqulat). Dari segi jenisnya, manfaat harta tak alih dihasilkan daripada tanah dan rumah. Manfaat daripada harta alih (manqul) pula terdiri daripada manfaat yang dihasilkan daripada haiwan, perabot dan kenderaan. Semua manfaat ini dikenali sebagai benda-benda yang nampak. Berbeza dengan hak cipta yang merupakan hasil pemikiran manusia atau hasil pemikir yang mempunyai ilmu, atau apa-apa yang dihasilkan penemu. Dari segi jenisnya, hasil inovasi diklasifikasikan sebagai perkara moral, dan manfaat harta benda pula diklasifikasikan sebagai manfaat harta benda.

Berdasarkan penjelasan al-Durayni tersebut, jelas menunjukkan terdapat perbezaan yang jelas antara harta ketara dan harta tidak ketara. Sejajar dengan itu, fuqaha telah memposisikan hak cipta dalam kategori hak moral yang merupakan pembahagian daripada hak harta (al-Khafif, 1966). Maka secara asasnya, hak cipta tidak termasuk dalam kategori harta alih atau pun harta tidak alih. Oleh itu, teori Suwaid tidak boleh digunakan dalam penentuan status hak cipta sebagai harta sepencarian. Namun demikian, jika ditinjau definisi harta sepencarian dalam Akta Undang-Undang Keluarga Islam (Wilayah-Wilayah Persekutuan) 1984, iaitu di dalam Seksyen 2, "harta sepencarian ditafsirkan sebagai harta yang diperoleh secara bersama oleh suami isteri semasa perkahwinan berkuat kuasa mengikut syarat-syarat yang ditentukan oleh hukum syarak."

Peruntukan tersebut menggunakan lafaz yang umum, iaitu "harta" yang menunjukkan bahawa apa-apa harta yang diperoleh dalam tempoh perkahwinan boleh dituntut sebagai harta sepencarian. Selanjutnya, teori ini turut disokong oleh kes yang pernah diputuskan oleh mahkamah seperti kes Roberts@Kamarulzamanv Ummi Kalthom [1981] 2 JH 82, harta sepencarian didefinisikan sebagai harta yang diperoleh dalam masa perkahwinan seorang suami dengan isterinya, hasil daripada sumber atau daripada usaha mereka. Takrifan ini turut digunakan dalam kes Hujah Lijah binti Jamal lwn Fatimah bt Mat Diah [1950] MLJ 63, apabila Hakim Briggs memberikan definisi harta sepencarian, iaitu sebagai harta yang diperoleh dalam masa mereka hidup berkahwin sebagai suami isteri, hasil daripada daya mereka atau melalui usaha mereka bersama. Berdasarkan perbincangan tersebut, pengkaji bersetuju dengan hujah yang mengatakan bahawa hak cipta boleh termasuk dalam kategori harta sepencarian kerana 
hak cipta termasuk dalam teori harta dan teori harta sepencarian seperti dalam perbincangan di atas.

Para pengamal perundangan syariah kontemporari dan ahli hak cipta bersetuju menerima status hak cipta sebagai harta sepencarian. Hal ini dipersetujui oleh Othman (2020) yang berpandangan hak cipta boleh termasuk dalam kategori harta sepencarian dengan melihat kepada teori harta sepencarian yang termaktub dalam peruntukan Akta Undang-Undang Keluarga Islam (Wilayah-Wilayah Persekutuan) 1984. Seperti pernyataan beliau:

Kalau kita pergi kepada tafsiran umum tadi, termasuklah. Boleh masuklah. Cuma sekarang bila kes takda ni kan, jadi kita tidak tahu bagaimana hakim mentafsirnya. Tapi kalau peribadi tanya sayalahkan, kalau ada kes yang macam tu, kita kena raikan juga lah. Cuma kalau hak dapat banyak mana tu, part yang kedua lah kan. Tapi boleh ke ia dituntut? Jawapannya bolehlah. Sebab kita pergi kepada tafsiran umum tadi kan.

Hal yang sama turut dipersetujui oleh Muhd Adil (2020) seperti yang berikut:

Jadi kalau ianya diperolehi di dalam perkahwinan, ianya boleh diiktiraf sebagai harta sepencarian. Kita kembali kepada undang-undang. Tafsiran di bawah Seksyen 2 Akta Undang-undang Keluarga Islam Wilayah, tentang harta sepencarian. Kalau negeri-negeri, di bawah enakmen lah. Harta sepencarian apa-apa yang diperolehi oleh suami isteri dalam tempoh perkahwinan, maka boleh diisytihar sebagai harta sepencarian. Selain itu boleh juga merujuk kepada perintah mahkamah dalam menyuruh pihak-pihak yang menuntut untuk mengagih "apa-apa aset" yang diperolehi di dalam tempoh perkahwinan.

Berdasarkan pernyataan di atas, kedua-kedua informan merujuk teori yang terdapat dalam Akta Undang-Undang Keluarga Islam (WilayahWilayah Persekutuan) 1984 untuk menentukan status hak cipta sebagai harta sepencarian. Hal ini menunjukkan bahawa, teori tersebut boleh menjadi asas dalam penentuan status hak cipta sebagai harta sepencarian jika terdapat tuntutan berkaitan hal ini. Hal yang sama turut disokong oleh Nazura Abdul (2020). Menurut beliau: 
Boleh, sebab dari awal lagi ianya telah diterima sebagai harta. Contohnya kalau Bill Gates tu bercerai, so isterinya tak boleh dapat apa-apalah? Boleh, sebab ianya sama seperti harta. Sebab benda itu ada nilai. Yang penting teorinya harta adalah sesuatu yang ada nilai.

Pernyataan di atas menunjukkan bahawa Nazura Abdul Manap (2020) turut menerima hak cipta sebagai harta sepencarian dengan melihat kepada prinsip hak cipta sebagai harta yang diiktiraf dan terdapat unsur bernilai padanya. Maka, berdasarkan kepada perbincangan definisi dari sudut teori kehartaan harta intelek atau hak cipta dan teori harta sepencarian, menunjukkan bahawa teori-teori ini disokong oleh pendapat ahli hak cipta dan pengamal perundangan syariah. Hal ini menunjukkan bahawa jika sesebuah karya itu dihasilkan atau dikembangkan dalam tempoh perkahwinan boleh termasuk dalam konsep harta sepencarian seperti yang difahami, dan teori ini boleh diaplikasikan.

\section{KRITERIA DALAM PENENTUAN SUMBANGAN SECARA LANGSUNG ATAU TIDAK LANGSUNG BAGI HAK CIPTA DALAM HARTA SEPENCARIAN}

Secara asasnya, sumbangan ditakrifkan sebagai sesuatu yang diberikan sebagai bantuan, pertolongan yang diberikan atau sokongan (Kamus Dewan Bahasa Edisi Keempat, 2010). Dalam penentuan bahagian yang layak untuk suami isteri dalam pembahagian harta sepencarian, terdapat beberapa kriteria yang dilihat. Antaranya termasuklah sumbangan secara langsung dan sumbangan secara tidak langsung suami dan isteri dalam perolehan harta. Hal ini akan dibincangkan seperti yang berikut.

\section{Sumbangan secara Langsung}

Sarjana membahagikan sumbangan secara langsung dalam tiga bentuk, iaitu pengumpulan harta atau modal, usaha ke arah menambahkan harta yang sedia ada, dan sumbangan lain seperti pandangan, nasihat serta dorongan (Siti Zalikhah, 1996). Lazimnya, sesuatu tuntutan yang dapat dipertimbangkan oleh mahkamah bergantung pada takat atau kadar sumbangan yang diberikan oleh pihak yang menuntut terhadap harta yang dikumpulkan dalam perkahwinan mereka. Hal ini selaras dengan yang telah diperuntukkan dalam Akta Undang-undang Keluarga Islam (Wilayah-Wilayah Persekutuan) 1984 Seksyen 58 (2), "Mahkamah hendaklah mengambil perhatian terhadap takat sumbangan yang telah 
dibuat oleh tiap-tiap satu pihak dalam bentuk wang, harta, atau kerja bagi memperoleh aset itu."

Pernyataan di atas merujuk kaedah penentuan harta sepencarian dengan melihat sumbangan secara langsung pihak isteri atau suami. Dalam peruntukan tersebut, sumbangan secara langsung boleh terdiri dalam bentuk wang, harta atau kerja untuk memperoleh aset tersebut. Dalam usaha menentukan hak cipta sebagai harta sepencarian, bagaimanakah sumbangan secara langsung dapat diukur dalam penghasilan sesebuah karya hak cipta seperti contoh dalam penghasilan karya sastera? Berkaitan hal ini, Othman (2020) mengemukakan bahawa:

Katakanlah, ada sesetengah saya baca buku yang tertentu, dia kata terima kasih kepada isteri saya sebagai jurutaip di bahagian penghargaan. Nampak tak? Perasan tak dalam sesetengah buku? Cuba cari kadangkadang banyak buku saya baca, buku Dr. Zul, saya akan baca kat situ. Contohlahkan kalau isteri yang nak tuntut, ada tak isteri kat situ? Kalau ada kat situ sumbangan secara langsunglah tu.

Penyataan di atas menunjukkan bahawa sumbangan secara langsung dalam penghasilan karya sastera atau hak cipta boleh diukur dengan melihat kepada bukti yang terdapat sepanjang penghasilan karya tersebut. Sebagai contoh pada bahagian penghargaan setiap karya ilmiah, kebanyakan penulis menyatakan penghargaan kepada pihak-pihak yang terlibat dalam penghasilan karya tersebut. Maka, penyataan berupa penghargaan ini boleh menjadi bukti kepada mahkamah untuk menentukan sama ada terdapat sumbangan secara langsung pihak suami atau isteri dalam penghasilan karya hak cipta mereka atau tidak.

\section{Sumbangan secara Tidak Langsung}

Sumbangan tidak langsung boleh ditakrifkan sebagai usaha yang disumbangkan oleh pasangan sama ada suami atau isteri untuk mendapatkan sesuatu harta sedangkan usaha yang disumbangkan adalah kecil berbanding dengan hasil atau manfaat yang dihasilkan daripada harta tersebut. Sumbangan secara tidak langsung boleh berupa idea, dorongan, nasihat, keselesaan, atau ketenteraman yang diberikan oleh salah satu pihak kepada pasangannya sehingga mendorong pasangannya berjaya dalam usaha mendapatkan sesuatu harta. Dalam penetapan harta sepencarian, elemen sumbangan tidak langsung di dalam rumah bergantung pada budi 
bicara mahkamah dengan mengambil kira status pihak yang memohon (Suwaid, 2003).

Peruntukan berkaitan dengan sumbangan tidak langsung disebut dalam enakmen setiap negeri, sebagai contoh dalam Enakmen Undangundang Pentadbiran Keluarga Islam (Negeri Terengganu) 1985, iaitu dalam Seksyen 57 subseksyen (4) menyebutkan:

Pada menjalankan kuasa yang diberi oleh subseksyen (3), Mahkamah hendaklah memberi perhatian kepada- (a) takat sumbangan-sumbangan yang telah dibuat oleh pihak yang tidak memperoleh aset itu kepada kebajikan keluarga dengan memelihara rumahtangga atau menjaga keluarga; ...

Berdasarkan peruntukan tersebut, sumbangan secara tidak langsung juga diambil kira dalam penentuan harta sepencarian. Hal ini lebih menjurus kepada sokongan moral daripada pihak suami atau isteri untuk mendapatkan harta sepanjang tempoh perkahwinan. Sumbangan secara tidak langsung ini dapat dilihat dalam kes Rokiah v Mohamed Idris [1986] $6 \mathrm{JH} 272$ dan Noor Bee v Ahmad Sanusi [1978] 1 JH 63. Untuk kes Rokiah v Mohamed Idris, mahkamah telah memutuskan bahawa pihak isteri berhak mendapatkan sebahagian daripada harta semasa perkahwinan mereka. Hal ini berdasarkan tugasan isteri dalam pengendalian rumah tangga dianggap sebagai sumbangan, dan usahanya bagi sesuatu harta yang diperoleh semasa perkahwinan. Sementara itu dalam kes Noor Bee v Ahmad Sanusi, kadi telah memutuskan bahawa khidmat isteri ketika dalam perkahwinan termasuklah membantu menguruskan rumahtangga haruslah diambil kira dalam pembahagian harta sepencarian. Oleh sebab itu, isteri berhak menerima sebahagian harta tersebut sebagai harta sepencarian.

Oleh itu, jika terdapat kes penentuan hak cipta sebagai harta sepencarian, elemen sumbangan tidak langsung juga turut diambil kira. Hal tersebut juga dinyatakan oleh Othman (2020):

Kalau tak sebut, tanya dia contohlah kan, karya sastera atau buku ni buat dekat mana? Rumah $k a$ ? Kalau buat kat rumah, isteri pun membantu. Dengan kopi dia $k a$, dak? Sebab orang menulis ni kadang-kadang sampai dua tiga pagi. Sebab generalnya macam tu, kita tak boleh nak bagi tepat. Undang-undang pun tak sebut begitu. Sebab ianya atas tafsiran hakimlah.

Pendapat yang sama turut dinyatakan oleh Muhd Adil (2020): 
Kalau dalam perkahwinan, ada karya sastera yang terhasil dalam masa perkahwinan, dan diterbitkan. Jadi, benda tu ada nilai, syarikat penerbitan akan bayar royalti. Jika karya itu usaha tunggal, pihak lagi satu tetap berhak ke atas royalti tersebut. Kerana pihak yang satu lagi telah memberi sumbangan secara tidak langsung. Dalam harta sepencarian mengambil kira sumbangan langsung dan tidak langsung. Sumbangan tidak langsung lebih kepada pihak isteri sebenarnya. Contohnya, dia menghasilkan karya sastera dalam rumah tangga dia. Sumbangan dari aspek moral support, menguruskan rumah tangga, menjaga anak. Biasa orang sastera ni dia akan duduk sorang-sorang kan. Jadi, bila dia duduk sorang-sorang secara tidak langsung telah melepaskan sedikit sebanyak tanggungjawab dia. Jadi, isteri yang menggunakan keringat untuk urusan keluarga, jaga anak, jaga dia (suami) sekali.

Pernyataan kedua-dua informan tersebut menjelaskan bahawa elemen sumbangan secara tidak langsung juga boleh diambil kira dalam penentuan status hak cipta sebagai harta sepencarian. Elemen sumbangan secara tak langsung juga bergantung pada tafsiran hakim dalam menilai bukti yang dikemukakan oleh pihak penuntut sama ada terdapat sumbangan secara tidak langsung dalam penghasilan karya tersebut atau tidak. Sumbangan secara tidak langsung merupakan sesuatu yang bersifat moral yang sukar diukur dan memerlukan ketelitian hakim dalam penilaiannya. Berdasarkan huraian tersebut, asas penentuan hak cipta sebagai harta sepencarian adalah dengan melihat elemen sumbangan suami dan isteri untuk mendapatkan harta sepanjang tempoh perkahwinan. Elemen sumbangan ini terdiri daripada sumbangan secara langsung dan sumbangan secara tidak langsung. Oleh itu, untuk menentukan status hak cipta sebagai harta sepencarian perlu melihat kepada elemen tersebut.

\section{Penentuan Kadar Hak Cipta sebagai Harta Sepencarian}

Secaranya amnya, tidak terdapat perbezaan pembahagian kadar harta sepencarian dalam apa-apa situasi atau keadaan tuntutan dibuat. Sama ada harta sepencarian tersebut dituntut dalam kes poligami, perceraian dan juga kematian salah satu pihak. Elemen yang diperhatikan dalam penentuan kadar ialah elemen sumbangan pihak-pihak yang menuntut. Hakim akan menentukan kadar peratusan yang diperoleh oleh suami dan isteri berdasarkan sumbangan sama ada secara langsung mahupun secara tidak langsung. Selain itu, dalam kes poligami, hakim juga melihat tarikh pihakpihak berkahwin secara sah mengikut hukum syarak dan tarikh sesuatu 
harta itu diperoleh oleh pihak suami dan isteri dalam perkahwinan mereka (Md. Yazid, Ahmad Muhammad \& Noor Lizza, 2014).

Penentuan kadar pembahagian harta sepencarian dijelaskan dalam Akta dan Enakmen Undang-undang Keluarga Islam negeri-negeri, sebagai contohnya dalam Seksyen 58 (2), Akta Undang-Undang Keluarga Islam (Wilayah-Wilayah Persekutuan) 1984 memperuntukkan:

Pada menjalankan kuasa yang diberi oleh subseksyen (1), Mahkamah hendaklah mengambil perhatian tentang-

(a) takat sumbangan-sumbangan yang telah dibuat oleh tiap-tiap satu pihak dalam bentuk wang, harta, atau kerja bagi memperoleh aset-aset itu;

(b) apa-apa hutang yang terhutang oleh salah satu pihak yang telah dilakukan bagi manfaat bersama mereka;

(c) keperluan-keperluan anak-anak yang belum dewasa dari perkahwinan itu, jika ada;

dan, tertakluk kepada pertimbangan-pertimbangan itu, Mahkamah hendaklah membuat pembahagian yang sama banyak.

Peruntukan tersebut menjelaskan bahawa mahkamah mestilah memerhatikan takat sumbangan secara langsung yang telah diberikan oleh pihak suami dan isteri dalam usaha memperoleh harta-harta mereka sepanjang tempoh perkahwinan mereka. Kadar pembahagian harta mestilah mengikut takat sumbangan pihak-pihak tersebut. Hal ini turut dikemukakan oleh Othman (2020), "kadar dia, kita tengok asas tadi. Adakah sumbangan secara direct, atau indirect tadi?" Pendapat ini juga turut disokong oleh Muhd Adil Yahaya (2020). Menurut beliau, "dari segi kadar pula, melihat kepada takat sumbangan secara langsung atau tidak langsung."

Berdasarkan pernyataan kedua-dua informan tersebut, menunjukkan bahawa jika terdapat sumbangan secara langsung atau tidak langsung dalam usaha memperoleh harta tersebut, mahkamah akan membuat pembahagian berdasarkan takat pelaburan yang telah dilakukan oleh pihak suami dan isteri. Othman (2020) dan Muhd Adil (2020) menyatakan bahawa jika pelaburan daripada pihak suami dan isteri sebanyak lima puluh peratus, maka pembahagiannya ialah lima puluh peratus kepada isteri dan lima puluh peratus kepada suami. Namun begitu, hal ini berbeza dengan pembahagian kadar untuk sumbangan secara tidak langsung seperti yang dinyatakan dalam seksyen 122:

(3) Mahkamah adalah mempunyai kuasa, apabila membenarkan lafaz talaq atau apabila membuat perintah perceraian, memerintah supaya 
aset-aset yang diperolehi dalam masa perkahwinan dengan usaha tunggal satu pihak kepada perkahwinan itu dibahagi antara mereka atau supaya aset itu dijual dan hasil jualan itu dibahagi antara mereka atau supaya mana-mana aset itu dijual dan hasil jualan itu dibahagi antara pihak-pihak itu.

(4) Pada menjalankan kuasa yang diberi oleh subseksyen (3), Mahkamah hendaklah memberi perhatian kepada-

(a) takat sumbangan-sumbangan yang telah dibuat oleh pihak yang tidak memperolehi aset itu, kepada kebajikan keluarga dengan memelihara rumahtangga atau menjaga keluarga;

(b) keperluan-keperluan anak-anakyang belum dewasa dari perkahwinan itu, jika ada, dan tertakluk kepada pertimbangan-pertimbangan itu, Mahkamah boleh membahagikan aset-aset itu atau hasil jualan itu, mengikut apa-apa kadar yang difikirkannya munasabah, tetapi, walau bagaimana pun, pihak yang telah memperoleh aset-aset itu dengan usahanya hendaklah menerima suatu kadar yang lebih besar.

Berdasarkan peruntukan tersebut, penentuan dan kadar pembahagian harta sepencarian bagi sumbangan secara tidak langsung tertakluk pada penilaian hakim dengan menilai sumbangan pihak-pihak seperti kebajikan keluarga dengan memelihara rumah tangga atau menjaga keluarga. Namun demikian, menurut peruntukan tersebut lagi, kadar yang lebih besar mestilah diberikan kepada pihak yang mengusahakan harta tersebut. Hal ini turut dikuatkan dengan ungkapan Othman (2020):

Penentuan kadar sumbangan secara tidak langsung bergantung pada keterangan. Kadang-kadang mahkamah bagi 40:60, 70:30. Sebab generalnya macam tu, kita tak boleh nak bagi tepat. Undang-undang pun tak sebut begitu. Sebab ianya atas tafsiran hakimlah. Tapi sebelum nak buat judgement dia tu, dia akan rujuklah berdasarkan keterangan dia ni, beban dia begini. Bukanlah kata bagi begitu je, tidak. Mesti ada sebab.

Hal ini juga turut disokong oleh Muhd Adil (2020):

Dari segi kadar pula, melihat kepada takat sumbangan secara langsung atau tidak langsung. Kita akan melihat kepada keadaan isteri, bekerja atau tidak bekerja, tempoh perkahwinan, sejauh mana dia menyumbang kepada menguruskan keluarga. Jika pasangan kurang memberikan sumbangan, mungkin kadar pembahagiannya akan kurang. 
Keterangan di atas secara tidak langsung telah menyokong asas penentuan kadar pembahagian harta sepencarian yang telah dinyatakan dalam Akta dan Enakmen Undang-undang Keluarga Islam Negeri-negeri. Oleh itu, dalam penentuan kadar pembahagian hak cipta sebagai harta sepencarian perlu melihat sumbangan yang telah diberikan pihak-pihak sama ada secara langsung atau pun tidak langsung dalam penghasilan karya hak cipta tersebut. Sebagai contoh, suami telah menghasilkan sebuah karya sastera. Ketika menyiapkan penulisan tersebut, isterinya telah menyumbangkan dana pelaburan atau memberikan idea dalam penulisan tersebut. Di sini dapat ditunjukkan bahawa terdapat sumbangan secara langsung isteri dalam penghasilan karya hak cipta tersebut. Oleh itu, isteri berhak menuntut haknya sesuai dengan kadar sumbangannya. Namun begitu, jika isteri tidak terlibat secara langsung dalam penghasilan karya tersebut, dia tetap berhak menuntut haknya bergantung pada sumbangannya membantu suami menguruskan rumah tangga seperti menjaga kebajikan keluarga. Dalam hal ini, mahkamah tidak boleh dengan sewenang-wenangnya menetapkan kadar pembahagian kerana mahkamah juga perlu menilai bukti-bukti atau keterangan yang telah diberikan oleh pihak suami dan isteri yang menuntut hak tersebut. Oleh sebab itu, penilaian hakim merupakan aspek yang penting dalam penetapan kadar pembahagian hak cipta sebagai harta sepencarian.

\section{Situasi yang Membolehkan Tuntutan Hak Cipta sebagai Harta Sepencarian}

Secara asasnya, harta sepencarian boleh dituntut dalam tiga keadaan, iaitu selepas perceraian, apabila suami ingin memohon untuk poligami dan kematian (Miszairi \& Akmal Hidayah, 2010; Nor Faizah, 2018). Berkenaan dengan tuntutan selepas perceraian, harta sepencarian termaktub dalam Akta dan Enakmen Undang-undang Keluarga Islam Negeri-negeri sebagai contoh, dalam Enakmen Undang-undang Keluarga Islam Negeri Selangor 2003, seksyen 122(1) memperuntukkan bahawa:

Mahkamah adalah mempunyai kuasa apabila membenarkan lafaz talaq atau apabila membuat suatu perintah perceraian untuk memerintah apaapa aset yang diperolehi oleh pihak-pihak itu dalam masa perkahwinan dengan usaha bersama mereka dibahagi antara mereka atau supaya manamana aset yang diperolehi pihak-pihak itu dalam masa perkahwinan dengan usaha bersama mereka dibahagi antara mereka atau supaya manamana aset itu dijual dan hasil jualan itu dibahagi antara pihak-pihak itu. 
Petikan di atas merujuk keadaan yang membolehkan tuntutan harta sepencarian dibuat, iaitu semasa tuntutan perceraian dilakukan atau selepas penceraian. Selain situasi tersebut, berkenaan dengan tuntutan harta sepencarian dalam keadaan poligami, hal ini dinyatakan dalam seksyen 23(10) seperti yang berikut:

Tiap-tiap mahkamah yang memberikan kebenaran atau memerintahkan perkahwinan itu didaftarkan di bawah seksyen ini, hendaklah mempunyai kuasa atas permohonan mana-mana pihak kepada perkahwinan

(b) untuk memerintahkan supaya apa-apa aset yang telah diperolehi oleh pihak-pihak itu dalam masa perkahwinan dengan usaha bersama mereka dibahagi antara mereka atau supaya mana-mana aset itu dijual dan hasil jualan itu dibahagikan.

Berdasarkan petikan di atas, jelas menunjukkan bahawa dalam kes poligami juga dibenarkan tuntutan harta sepencarian. Kedua-dua situasi ini telah diperkuat dengan dikeluarkan satu Arahan Amalan No.5 Tahun 2003 yang telah dikeluarkan oleh Jabatan Kehakiman Syariah Malaysia. Dalam arahan tersebut dinyatakan bahawa: "masa membuat tuntutan harta sepencarian dibolehkan sama ada semasa tuntutan perceraian, selepas perceraian ataupun selepas kematian mana-mana pihak".

Namun demikian, bagi tuntutan dalam kes kematian belum terdapat peruntukan khusus mengenainya. Hal ini hanya dinyatakan dalam Arahan Amalan No.5 Tahun 2003 yang telah dikeluarkan oleh Jabatan Kehakiman Syariah Malaysia seperti petikan di atas. Untuk memperkuat arahan tersebut, terdapat s fatwa yang telah diwartakan oleh Negeri Selangor pada $23 \mathrm{hb}$ Jun 2005 yang menyebut bahawa harta sepencarian selepas kematian salah satu pihak dalam perkahwinan di Negeri Selangor boleh dibahagikan kepada suami atau isteri sebelum difaraidkan termasuk setelah dilepaskan tanggungan si mati.

Bagi mengukuhkan dapatan tersebut, pengkaji turut mengajukan hal ini kepada beberapa informan yang merupakan pengamal perundangan Syariah. Hasil temu bual antara pengkaji dengan Informan 1 dan Informan 2 menunjukkan bahawa situasi yang membolehkan tuntutan harta sepencarian dibuat adalah selari. Seperti yang dinyatakan oleh Othman (2020), "harta sepencarian tu biasa selepas bercerailah. Harta sepencarian juga boleh dituntut dalam keadaan poligami dan kematian". Pendapat ini turut disokong oleh Muhd Adil (2020). Menurut beliau: 
Ianya ada tiga keadaan, pertama apabila berlaku perceraian, kedua apabila berlaku kematian dan ketiga apabila berlaku poligami. Jadi selain daripada keadaan ini, tidak boleh dituntut.

Berdasarkan perbincangan tersebut, tuntutan hak cipta sebagai harta sepencarian boleh dilakukan dalam tiga keadaan, iaitu semasa atau selepas perceraian, poligami dan kematian pihak isteri atau suami.

\section{Perintah yang Melibatkan Pihak Ketiga dalam Pembayaran Royalti}

Berkenaan dengan perintah mahkamah terhadap pihak ketiga dalam pembayaran royalti hak cipta, tidak terdapat sebarang peruntukan mengenainya. Pembayaran royalti kebiasaannya tertakluk pada kontrak perjanjian antara penerbit dengan penulis. Namun demikian, dalam pelaksanaan pembayaran royalti kepada pihak isteri dan suami, bolehkah Mahkamah mengeluarkan arahan kepada pihak penerbit atau pihak ketiga tersebut? Berkenaan hal ini, Othman (2020) mengemukakan bahawa mahkamah boleh mengeluarkan arahan kepada penerbit untuk membayar royalti kepada pihak suami dan isteri berdasarkan kadar yang telah ditetapkan oleh mahkamah. Seperti yang beliau kemukakan, iaitu:

Royalti tu, kalau ditafsirkan sebagai harta sepencarian ni tadi, bolehlah. Pembayaran ni, itu tatacara bayar saja. Katakanlah duit ada pada penerbit, kita boleh arahkan penerbit suruh bayar.

Hal tersebut juga turut disepakati oleh Muhd Adil (2020), menurut beliau:

Perintah mahkamah tidak boleh dikenakan kepada pihak yang ketiga atau pihak luar. Mahkamah akan tentukan kadar-kadar kepada pihakpihak sahaja. Cuma untuk melaksanakan hak pihak-pihak tersebut, boleh melalui saluran pihak ketiga. Ianya lebih kurang seperti tuntutan nafkah. Jika sekiranya suami enggan membayar nafkah, mahkamah mengeluarkan perintah ke atas suami tersebut. Jadi kita boleh gunakan saluran ketiga, sebagai contoh potong gaji atau mengeluarkan arahan kepada pihak ketiga untuk membayar royalti tersebut.

Berdasarkan kenyataan tersebut, jelas menunjukkan bahwa mahkamah tidak boleh mengeluarkan perintah kepada pihak ketiga. Namun demikian, mahkamah boleh mengarahkan pihak ketiga sebagai contoh dalam kes tuntutan yang melibatkan karya ilmiah, royalti akan dibayar oleh penerbit 
kepada penulis. Dalam kes ini, mahkamah boleh mengarahkan penerbit untuk membayar royalti kepada pihak isteri dan suami mengikut kadar yang telah ditentukan oleh mahkamah.

\section{Sumber Hukum Hak Cipta sebagai Harta Sepencarian}

Pada dasarnya, belum terdapat sebarang peruntukan khusus yang boleh dijadikan asas untuk menetapkan status hak cipta sebagai harta sepencarian. Namun demikian, penulisan tentang fuqaha boleh menjadi asas dalam penentuan hal ini. Di Malaysia, petikan dalam kitab fiqh telah menjadi asas mahkamah syariah untuk menentukan harta sepencarian dan kaedah penyelesaiannya. Antaranya termasuklah petikan daripada kitab al-Umm dan petikan daripada kitab Bughyah Al-Mustarshidin.

Secara umumnya, petikan daripada kitab al-Umm (al-Shafici, 1993) dan Bughyah al-Mustarshidin (Bacalwi, 1978) hanya menyebut harta benda dan perkakas rumah yang menjadi perebutan antara suami dan isteri serta kaedah penyelesaiannya. Petikan ini tidak merujuk takrifan harta sepencarian seperti yang difahami pada masa kini. Namun demikian, menurut Othman (2020), istilah harta benda dan perkakas rumah yang dinyatakan dalam teks tersebut boleh diperluas dan diaplikasikan sesuai dengan konteks masa kini. Harta benda didefinisikan sebagai barang kepunyaan atau berbagai-bagai barang berharga, manakala perkakas rumah pula bermaksud bahan untuk membuat rumah atau perabot (Dewan Bahasa dan Pustaka 2010). Jika difahami, hak cipta boleh termasuk dalam konteks ini kerana hak cipta sesuatu yang berharga dan diiktiraf sebagai harta yang memiliki nilai seperti yang telah dibincangkan oleh pengkaji dalam perbahasan teori hak cipta sebagai harta sepencarian. Berkenaan landasan hukum hak cipta sebagai harta sepencarian, Othman Ibrahim (2020) telah mengemukakan bahawa:

Secara umumnyalahkan, ini yang dalam kitab al-Umm (sambil menunjukkan petikan arab dalam kitab al-Umm). Ini sebagai contoh menunjukkan pertelingkahan benda-benda dalam perkahwinan yang berlaku pada zaman Imam Shafii. Kalau kita ikut yang ini, memang tak berlakulah tuntutan-tuntutan yang sekarang ni. Zaman sekarang ni ada saham, zaman dulu belum ada saham. Saham, share dan sebagainya. Kita tidak tahu masa depan nanti apa pula yang akan muncul. Macam hak cipta kan, termasuklah dalam perbahasan ini mengikut konteks sekarang. Sebab konsep asal tadi, harta yang diperoleh bersama dalam tempoh perkahwinan. Barulah kita nampak hukum syarak berkembang 
seiring zaman. Apa-apa yang dibahaskan dalam kitab Imam Shafii ini adalah yang berlaku di zaman dia. Sebab itu hukum dalam setiap mazhab berbeza-beza sebab mengikut kepada keadaan dan masyarakat setempat.

Ungkapan tersebut menunjukkan bahawa Othman (2020) menjadikan teks daripada kitab al-Umm untuk menentukan status hak cipta sebagai harta sepencarian. Seperti yang dikatakan beliau, Imam Shafici mengemukakan hal tersebut berdasarkan kepada konteks yang berlaku pada zamannya. Oleh itu, jika difahami teks tersebut juga boleh diaplikasikan berdasarkan kepada konteks masa kini. Hal ini menunjukkan bahawa hukum Islam tidak statik. Hukum Islam juga berkembang sesuai dengan peredaran zaman. Berdasarkan perbahasan tersebut, asas hak cipta sebagai harta sepencarian adalah dengan melihat kepada sumber yang telah dibahaskan oleh fuqaha seperti dalam kitab al-Umm dan Bughyah al-Mustarshidin. Hal ini menunjukkan bahawa, mahkamah juga boleh merujuk asas ini sebagai rujukan dalam penyelesaian kes tuntutan hak cipta sebagai harta sepencarian.

Selain itu, menurut Mohamad Ashraf Sulaiman (2020), kaedah fiqh yang boleh digunakan untuk menetapkan hak cipta sebagai sebagai harta sepencarian adalah dengan mengaplikasikan kaedah (Ibn Nujaym, 1999), yang bermaksud: "Asal kekal sesuatu itu mengikut apa-apa yang ada sebelumnya".

Seperti ulasan Mohamad Ashraf (2020) berkenaan kaedah di atas, "dalam kes ini, hal ini bermaksud royalti itu kekal milik suami selagi belum terbukti bahawa royalti juga milik isteri." Berdasarkan pendapat informan tersebut, dalam kes tuntutan hak cipta sebagai harta sepencarian, royalti yang dituntut itu adalah kekal milik pemunya sama ada isteri atau suami selagi belum terbukti bahawa terdapat sumbangan pihak-pihak dalam penghasilan karya tersebut. Keputusan ini juga tertakluk pada hakim untuk menilai sumbangan pihak-pihak tersebut seperti yang dijelaskan oleh pengkaji dalam perbahasan sebelum ini.

\section{CADANGAN KAJIAN}

Berdasarkan hasil kajian, pengkaji ingin mencadangkan kepada pihak berwajib seperti penggubal perundangan Akta dan Enakmen Undangundang Keluarga Islam di Malaysia, iaitu cadangan menggubal undangundang harta sepencarian pada peringkat parlimen dengan mentafsirkan atau mengkategorikan harta-harta yang boleh dituntut sebagai harta 
sepencarian dengan memasukkan harta intelek atau hak cipta sebagai kategori harta yang boleh dituntut sebagai harta tersebut, iaitu dengan menggunakan terma harta tidak ketara. Hal ini akan lebih memudahkan masyarakat yang kurang pendedahan berkenaan hal tersebut untuk memahami harta-harta yang boleh dituntut sebagai harta sepencarian.

Selain itu, penggubal undang-undang sivil juga boleh menggubal Akta Hak Cipta 1987 dengan memasukkan berkenaan tuntutan royalti yang melibatkan harta sepencarian. Oleh itu, hal tersebut lebih memudahkan jika sekiranya terdapat tuntutan harta sepencarian dibuat apabila ada peruntukan yang menjadi panduan kepada masyarakat yang bertelingkah tentang tuntutan hak cipta sebagai harta sepencarian. Kajian ini juga mencadangkan supaya perlu digiatkan penulisan berkaitan dengan hak cipta dari aspek Islam. Kempen berkenaan hak cipta perlu diperbanyak supaya masyarakat mendapat pendedahan berkenaan ilmu hak cipta. Hal ini juga bertujuan supaya perkara yang berkaitan dengan monopoli royalti hak cipta tidak berlaku. Kesedaran masyarakat penting, khususnya suami dan isteri, yang sama-sama berkarya atau memperoleh hak cipta dalam tempoh perkahwinan atau sama-sama mengembangkan karya atau ciptaan tersebut dalam tempoh perkahwinan mereka supaya mereka boleh menuntut hak mereka jika sekiranya terjadi perceraian, poligami atau kematian salah satu pihak.

\section{KESIMPULAN}

Berdasarkan perbincangan, beberapa kesimpulan dapat dibuat, iaitu yang pertama, hak cipta dapat dikategorikan sebagai harta sepencarian kerana dengan melihat kepada teori asalnya, iaitu hak cipta termasuk dalam kategori harta yang diiktiraf oleh syarak kerana hak cipta mempunyai ciri-ciri bernilai, bermanfaat dan boleh dimiliki. Hal ini berbeza dengan pendapat mazhab Hanafi yang tidak menerima hak cipta sebagai kategori ini. Selanjutnya, hak cipta juga boleh dikategorikan sebagai harta yang boleh dituntut sebagai harta sepencarian kerana, peruntukan tidak mengehadkan jenis-jenis harta yang boleh dituntut sebagai harta sepencarian. Selain itu, hasil dapatan temu bual juga menunjukkan bahawa ahli hak cipta dan pengamal perundangan syariah turut menerima hak cipta sebagai harta sepencarian berdasarkan teori-teori kehartaan dan konsep harta sepencarian. Hal ini menunjukkan bahawa, hukum syarak yang berkaitan fiqh berkembang mengikut peredaran zaman. Hal ini kerana, jika ditinjau kes-kes yang tuntutan harta sepencarian sebelum ini 
hanya melibatkan harta alih dan harta tidak alih sahaja. Namun demikian, terdapat kes yang berkaitan dengan tuntutan harta tak ketara sebagai harta sepencarian pernah dikemukakan dalam sebuah kajian yang dibincangkan oleh pengkaji sebelum ini.

Kriteria yang diambil kira dalam penentuan status hak cipta sebagai harta sepencarian juga adalah dengan melihat kepada elemen sumbangan pihak suami dan isteri dalam penghasilan karya hak cipta tersebut dalam tempoh perkahwinan mereka. Royalti juga boleh dituntut selepas perceraian, kematian salah satu pihak dan jika suami berpoligami. Penentuan kadar pula tertakluk pada penilaian hakim dalam penilaian sumbangan secara langsung atau tidak langsung pihak isteri dan suami dalam penghasilan hak cipta tersebut sepanjang perkahwinan mereka. Mahkamah syariah juga boleh menjadikan petikan dalam kitab Bughyah al-Mustarsyidin dan al-Umm sebagai rujukan asas untuk menyelesaikan kes tuntutan hak cipta sebagai harta sepencarian. Selagi pihak suami dan isteri tidak mampu membuktikan terdapat sumbangan mereka dalam penghasilan sesebuah karya hak cipta, maka hak pemilikan terhadap karya tersebut tetap menjadi hak milik empunya karya tersebut sama ada suami atau isteri. Hal ini bertepatan dengan kaedah fiqh yang bermaksud "Asal kekal sesuatu itu mengikut apa yang ada sebelumnya".

\section{RUJUKAN}

Akta Hak Cipta 1987 [Akta 332]

Akta Undang-Undang Keluarga Islam (Wilayah-Wilayah Persekutuan) 1984

Bacalwi, Abd al-Rahman ibn MuÍammad ibn Usayn ibn Umar. (1978). Bughyah al-Mustarshidin fi Talkhish Fatawa Ba'd al-A'immah al-Muta'akhirin. Dar al-Macrifah.

al-Bahuti, Mansur ibn Yunus ibn Idris. (2000). Sharh Muntaha al-Iradat Daqa'iq awla al-Naha li Sharh al-Muntaha (Juz 3). t.tp.: Mu'assasah al-Risalah.

al-Durayni, Fathi. (1981). Haq al-Ibtikar fi al-Fiqh al-Islami al-Muqaran. Muassasah al-Risalah.

al-Khafif, Ali. (1966). Al-Milkiyyah fi al-Sharicah al-Islamiyyah maca alMuqaranah bi al-Sharaci al-Wadciyyah. Macahad al-Buhuth wa al-Dirasat al-cArabiyyah.

al-Maqdisi, Muhammad bin Qudamah. (2000). al-Muqnic fi Fiqh al-Imam Ahmad bin Hanbal al-Shaybani. Maktabah al-Sawadi.

al-Qarafi, Abu Abbas Ahmad ibn Idris. (1998). al-Furuq. Dar al-Kutub alAlamiyyah.

al-Shafici, Abi Abdillah Muhammad ibn Idris. (1993). al-Umm (Juz 5). Dar alKutub al-Alamiyyah. 
al-Suyuti, Jalal al-Din Abd al-Rahman. (1983). al-Ashbah wa al-Naza'ir $f i$ Qawacid wa Furuc Fiqh al-Shaficiyyah. Dar al-Kutub al-Alamiyyah.

al-Zarkashi, Badr al-Din Muhammad ibn Bahadur. (2000). al-Manthur fi alQawacid li al-Zarkashi. Juz 3. Dar al-Kutub al-Alamiyyah.

al-Zuhayli, Wahbah. (1985). al-Fiqh al-Islami wa Adillatuh. Dar al-Fikr.

D. Moore, Adam. (1998). Intangible property: Privacy, power, and information control. American Philosophical Quartefly, 35(4), 365-378.

Enakmen Undang-Undang Pentadbiran Keluarga Islam Terengganu 1985. Hujah Lijah binti Jamal v Fatimah bt. Mat Diah [1950] 3 LNS 1; MLJ 63.

Ibrahim Lembut. (2010). Harta sepencarian: konsep dan amalan. Prosiding Seminar Pengurusan Harta Islam Peringkat Kebangsaan. Jabatan Syariah, Fakulti Pengajian Islam, UKM.

Ibrahim, N \& Abd Ghaddas. (2017). Claims of intangible interest as matrimonial property at Shari'ah Courts: a special references to Kelantan, Terengganu and Malacca. Pertanika J. Soc. Sci. \& Hum, 25(S), 97-104.

Ibn Abd al-Barr. (1998). Fath al-Malik (Jilid 6). Dar al-Kutub al-cIlmiyyah.

Ibn Abidin, Muhammad Amin al-Shahir. (2003). Radd al-Muhtar Kitab al-Buyuc (Juz 9). Dar Alim al-Kutub.

Ibn Hazm, Ali ibn Ahmad. (2015). al-Muhalla. Dar al-Kutub al-Ilmiyyah.

Ibn Nujaym, Zayn al-Din ibn Ibrahim ibn Muhammad. (1999). Al-Ashbah wa alNaza'ir cala Madhhab Abi Hanifah al-Nucman. Dar al-Kutub al-cIlmiyyah.

Kamus Dewan Bahasa dan Pustaka (Edisi Keempat). (2010). Dewan Bahasa dan Pustaka.

Majallat al-Ahkam al-Adliyah. (1991). Undang-undang Sivil Islam. (Terj. Md. Akhir Haji Yaacob). Dewan Bahasa dan Pustaka.

Md. Yazid Ahmad, Ahmad Muhammad Husni \& Noor Lizza Mohamed Said. (2014). Pembahagian harta sepencarian dalam poligami menurut undangundang keluarga Islam. Isu Syariah \& Undang-Undang (Siri 20), hlm. 92106. Jabatan Syariah, Fakulti Pengajian Islam, UKM.

Miszairi Sitiris \& Akmal Hidayah Halim. (2010). Tuntutan harta sepencarian dalam kes kematian. Kanun Jurnal Undang-undang Malaysia, 22(1), 26-46.

Mohamad Ashraf Sulaiman. (2020). Hukum dan kaedah fiqh yang digunakan dalam menetapkan hak cipta sebagai harta sepencarian. Putrajaya: Temu bual, 17 Februari.

Muhd Adil Yahaya. (2020). Tuntutan hak cipta sebagai harta sepencarian. Kuala Lumpur: Temu bual, 13 Februari.

Mohd Nurhusairi Mat Husin. (2014). Konsep sumbangan dalam penentuan pembahagian harta sepencarian di Mahkamah Syariah Malaysia: Perspektif sosio-perundangan (Tesis Doktor Falsafah tidak diterbitkan). Jabatan Syariah dan Undang-undang, Akademi Pengajian Islam, Universiti Malaya.

Nazura Abdul Manap. (2020). Hak cipta sebagai harta sepencarian menurut perspektif sivil. Selangor: Temu bual, 5 Mac. 
Noor Bee v Ahmad Sanusi [1978] 1 JH 63

Nor Faizah Zakaria. (2018). Tuntutan Harta Sepencarian dalam Poligami Menurut Undang-Undang Islam di Malaysia (Disertasi Sarjana tidak diterbitkan). Jabatan Syariah, Fakulti Pengajian Islam, Universiti Kebangsaan Malaysia.

Othman Ibrahim. (2020). Tuntutan hak cipta sebagai harta sepencarian. Putrajaya: Temu bual, 14 Februari.

Roberts@Kamarulzaman v Ummi Kalthom [1981] 2 JH 82

Rokiah v Mohamed Idris [1986] 6 JH 272

Salmond, John W. (1913). Jurisprudence. The Ballantynes Press.

Siti Zalikhah Md. Nor. (1996). Pemilikan harta dalam perkahwinan. Dewan Bahasa dan Pustaka.

Suwaid Tapah. (1996). Konsep dan amalan pembahagian harta sepencarian orang-orang Islam di Malaysia (Tesis Doktor Falsafah tidak diterbitkan). Fakulti Sastera dan Sains Sosial, Universiti Malaysia.

Suwaid Tapah. (2003). Harta sepencarian dan wang simpanan pekerja (KWSP): Suatu perbincangan dari sudut sumbangan secara tidak langsung. Jurnal Syariah, 11(2), 1-22. 